\title{
Wood Carving Motifs On Traditional Aceh Houses In Delima District (Pidie, Indonesia)
}

\author{
Novita Novita $^{1,2}$, Hasbi Amiruddin ${ }^{1}$, Husaini Ibrahim ${ }^{1}$, Teuku Muhammad Jamil ${ }^{1}$ \\ \{novita@unsyiah.ac.id ${ }^{1}$ \} \\ ${ }^{1}$ Graduate School of Social Science, Syiah Kuala University, Darussalam 2311, Banda Aceh, Indonesia. \\ ${ }^{2}$ Department of Vocational and Social Welfare, Faculty of Teacher Training and Education, Syiah Kuala \\ University, Darussalam 2311, Banda Aceh, Indonesia
}

\begin{abstract}
Wood carving on Aceh traditional house is one of the Indonesian traditional heritages that has been passed through generations and should be preserved. This study aims to explore and identify motifs engraved on the Aceh traditional houses in Delima district, Pidie, Aceh Province, Indonesia. Data obtained by direct surveys to fields and interviewed owners of Aceh traditional houses, woodcarvers, and community leaders. Site visits to the chosen houses are carried out where the processes of data collecting. Secondary data were obtained from literatures and manuscripts. We found many traditional houses in some places which own interesting motifs. Woodcarving motifs on the Aceh traditional houses are dominated by elements from flora and nature. Geometric patterns applied around the engravings. A number of selected object for the houses are dominated by clouds, stars, mountains, curved lines, straight lines, geometry patterns and the woodcarver is one of the most understandings on motifs and carving techniques. The carving was commonly applied at the roof end as fascia boards, on windows, on the walls, and other parts.
\end{abstract}

Keywords: Aceh traditional house, Delima district, motifs, woodcarving, pattern.

\section{Introduction}

Aceh is a special territory of Indonesia, located on the northern tip of the island of Sumatra. It is also proudly referred to as the "Port to Meccah", as Islam first arrived in Aceh before spreading throughout Southeast Asia [1]. While based on historical research, the Acehnese are a mixture of Arab, Indian, Chinese and Portuguese [2]. Aceh was the first area that strongly influenced the culture of Islam in Indonesia, and it's affected a profound effect on all aspects of community life, particularly in law, cultural, and arts. As a region that is developing the rules of Islam, the people of Aceh interpret as cover aurat clothing, apparel as one form of execution as a form of religion and identity. Motif is a design create from various shapes, lines or elements that are sometimes strongly influenced by the stylized forms from natural objects, with style and distinctive characteristics [3]. The distinctive character on the TAH is the diversity of motifs that are placed on certain parts as decorative ornaments. The TAH decorated with various ornaments found on the walls (binteh), doors (pinto), ventilation (jeurejak) and "tulak angeen" [4]. Motifs found in the Aceh traditional houses have a very high artistic value, but knowledge of the society for traditional motifs has been forgotten due to the 
rapid urbanization. Therefore, it is important to study on the woodcarving found in the traditional Aceh houses in Pidie. This research is focusing on Delima District due to its strong historical factors as well as its relatively huge amount of Aceh traditional houses compared to other districts in Pidie.

\section{Methods}

Qualitative methods (Somantri 2005) has applied in the study since March to August 2018. Population covers all the Aceh traditional houses within Delima district, whereas samples taken as the object of this research is the houses as recommended by informants. The accuracy of the data source is a very important aspect in this study. Primary data were obtained through direct observation of the various motifs found on the Aceh traditional houses. Interviews were conducted with a number of respondents: owners, museum employees, community leaders, and woodcarvers. Secondary data for this study were obtained from books, documents, manuscripts, articles, magazines. The selected motif then drawn on A4 size paper and any information for each motif is also recorded. Information about the meaning and significance of the motifs obtained by visiting people who have knowledge about the motifs: cultural institutions and customs, museum, woodcrafter, and the community leaders.

\section{Results And Discussion}

The result of the analysis reveals that Aceh traditional houses in Delima district are consisting of a variety of shapes and pattern. Each motif is created in the design process of from an object, while pattern may be seen, as a whole within with motif is a central theme. In my observation, the perfection in a motif on Aceh traditional houses are produced when the pattern drawn are clear, define, and fit for the form created. For example, the motif of the blooming flower should display the stalk, sepal, petals, and others. Only when it complete, then, a certain composition is considered perfect and beautiful.

Generally, a number of motifs on the Aceh traditional houses are divided into two parts: Geometric motif (straight lines, broken lines, parallel lines, and circles) and natural motifs (elements of plants and animals). Islam affects every aspect of community life in Delima, including art crafts on the Aceh traditional houses. This indication reflected by a few number of motif from fauna. Islam forbid in making shapes of living things because it will be held accountable in the Hereafter. Therefore, those motifs dominated by a variety of materials from the flora and natural surroundings. These motifs also found in other Aceh traditional houses [5] A number of selected object for the Aceh traditional houses are dominated by clouds, stars, mountains, curved lines, straight lines, geometry and others [6]; [7]. Actually motifs on the Aceh traditional houses in Delima are very diverse and varied. We need more time and manpower to explore them. In this study, the woodcarvers are most important in understanding of motif meaning so far. Floral motifs on the houses mostly inspired from plants that growing around the society. In several houses, in order to look more artsy, we found that the motifs are combined with the various objects from nature. In addition, these motifs are also dominated by geometric patterns such as a triangle, rectangle, rectangular, hexagonal, and others. Various motifs on Aceh traditional houses presented in Table 1. 
Table 1. Motifs and decorating sites on the Aceh traditional houses at Delima District.

\begin{tabular}{|c|c|c|c|}
\hline No & Local name & Common name & Decorating site \\
\hline 1 & $\begin{array}{l}\text { Awan Si Oen, Pucok } \\
\text { Rebong }\end{array}$ & $\begin{array}{l}\text { Cloud, bamboo } \\
\text { shoots }\end{array}$ & $\begin{array}{l}\text { Ventilation (wall), } \\
\text { window }\end{array}$ \\
\hline 2 & $\begin{array}{l}\text { Awan Si Oen, Oen Murong, } \\
\text { Awan Meucanek }\end{array}$ & $\begin{array}{l}\text { Cloud, moringa } \\
\text { leaves }\end{array}$ & $\begin{array}{l}\text { Ventilation } \\
\text { (door), wall }\end{array}$ \\
\hline 3 & $\begin{array}{l}\text { Pucok Rebong, Bang-bang, } \\
\text { Pucok Paku }\end{array}$ & $\begin{array}{l}\text { Bamboo shoots, } \\
\text { butterfly, fern leaf }\end{array}$ & $\begin{array}{l}\text { Ventilation (door, } \\
\text { wall) }\end{array}$ \\
\hline 4 & $\begin{array}{l}\text { Awan Si Oen, Boengong, } \\
\text { Kupula, Putik Boengong }\end{array}$ & $\begin{array}{l}\text { Cloud, flower } \\
\text { pistil, kupula } \\
\text { flower }\end{array}$ & $\begin{array}{l}\text { Ventilation (door: } \\
\text { above site on } \\
\text { rectangular area), }\end{array}$ \\
\hline 5 & Boengong Ukheu Cina & $\begin{array}{l}\text { Bunga } \\
\text { China flower root, } \\
\text { flower sequential, } \\
\text { Bunga akar cina }\end{array}$ & $\begin{array}{l}\text { and wall } \\
\text { Wall (outside), } \\
\text { pole slippers }\end{array}$ \\
\hline 6 & $\begin{array}{l}\text { Boengong Meusingklet, } \\
\text { Gigoe Darut, Boengong } \\
\text { Kipah, Batei Bedei }\end{array}$ & $\begin{array}{l}\text { dental } \\
\text { grasshoppers, } \\
\text { flower on hand } \\
\text { fan shape }\end{array}$ & Wall \\
\hline 7 & Boengong sitangkei & Ties floral sprig & Door \\
\hline 8 & Taloe meuputa, Bang-bang & $\begin{array}{l}\text { Rope spinning, } \\
\text { butterfly }\end{array}$ & Pole slippers \\
\hline 9 & $\begin{array}{l}\text { Boengong Mata Uroe, Putik } \\
\text { boengong, Boh Rambot }\end{array}$ & $\begin{array}{l}\text { Sunflower, pistil, } \\
\text { rambutan fruit }\end{array}$ & Wall \\
\hline 10 & $\begin{array}{l}\text { Oen Ranup, Boengong } \\
\text { Meusingklet. }\end{array}$ & $\begin{array}{l}\text { Betel leaves, floral } \\
\text { concatenated }\end{array}$ & Wall \\
\hline 11 & $\begin{array}{l}\text { Boengong Meulu, Pucok } \\
\text { Paku, Awan Meucanek, Oen } \\
\text { Murong }\end{array}$ & $\begin{array}{l}\text { Jasmine, fern leaf, } \\
\text { clouds, moringa } \\
\text { leaves }\end{array}$ & Door \\
\hline 12 & $\begin{array}{l}\text { Pucok Reubong, Bungong } \\
\text { Meulu, Awan Si Oen, On } \\
\text { Murong }\end{array}$ & $\begin{array}{l}\text { Bamboo shoots, } \\
\text { jasmine, cloud, } \\
\text { moringa leaves }\end{array}$ & Ventilation \\
\hline 13 & $\begin{array}{ll}\text { Puta Taloe, } & \text { Boengong } \\
\text { Meusingklet, } & \text { Pucuk labu }\end{array}$ & $\begin{array}{l}\text { Rope spinning, } \\
\text { floral } \\
\text { concatenated, } \\
\text { shoots pumpkins }\end{array}$ & Wall, pole \\
\hline
\end{tabular}

The selection and placement of a motif is determined by the function space carved. More space will provide a greater number of motifs or more. 


\section{Conclusion}

1. Motifs on the Aceh traditional houses in Delima district are dominated by elements from flora and nature as well as geometric patterns. The objects are frequently used in the artwork is clouds and stars.

2. In order to look more artsy, various motifs are combined with objects in nature.

3. People who understand the meaning of motif is rare and carpenter is one of the most understandings of the motifs so far.

\section{Acknowledgements}

We would like to express my cordial thanks to informants, community leaders and woodcarvers in Delima District for their encouragement and advice. We also would like to express our sincere thanks to the government and society in Pidie for their various help and supports. This work was partly supported by Penelitian Disertasi Doktor (DGHEI, Indonesia) Research Grant to Novita 2018.

\section{References}

[1] A. Marshal, How an escape artist became Aceh's governor. USA: Time Magazine, 2007.

[2] A. Hasymi, Sejarah Kebudayaan Islam. Jakarta: PT. Bulan Bintang, 1995.

[3] H. Suhersono, Desain Bordir Inspirasi Motif Tradisional Jepang. Jakarta: Gramedia Pustaka Utama, 2005.

[4] S. A. Musa, Seni Rupa Aceh. Banda Aceh, 1996.

[5] E. Warningsih and Nuralam, "Ragam Hias Tradisional Aceh," in Bulletin Rumoh Aceh No. 2., 1999.

[6] V. der Hoop, Ragam-ragam Perhiasan Indonesia. Jakarta: Bataviansch Genoothschap Van Kunsten en Weteschappen, 1949.

[7] Surfida, "Motif 'Pinto Aceh' pada kerajinan emas H. Harun Keuchik Leumik di Banda Aceh," Sekolah Tinggi Seni, Padang Panjang, 2003. 